\title{
Postoji li mogućnost povećanja učinkovitosti hrvatskih poreznih vlasti?
}

Bronić, Mihaela; Bratić, Vjekoslav

Source / Izvornik: Odabrani prijevodi, 2014, 5, 1 - 19

Journal article, Published version

Rad u časopisu, Objavljena verzija rada (izdavačev PDF)

https://doi.org/10.3326/op.24

Permanent link / Trajna poveznica: https:/urn.nsk.hr/urn:nbn:hr:242:986153

Rights / Prava: Attribution-NonCommercial-NoDerivatives 4.0 International/ImenovanjeNekomercijalno-Bez prerada 4.0 međunarodna

Download date / Datum preuzimanja: 2023-04-26

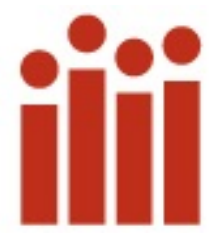

Institute of Public Finance Repository

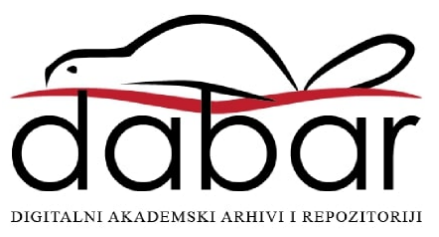


Institut za

javne financije

Smičiklasova 2I | Zagreb

www.ijf.hr | ured@ijf.hr

T: oI/4886-444 | F: oI/48I9-365

\section{OdABRANI}

\section{PRIJEVODI}

ISSN 1847-7445

BR. 24/I4

citirati: Bronić, M. i Bratić, V. 2014. Can the efficiency of the Croatian tax authorities be improved?. Financial Theory and Practice, 38 (3), str. 253-275. http://fintp/upload/files/ftp/20I4/ 3/bronic_bratic.pdf

Svi Odabrani prijevodi dostupni su na: http://www.ijf.hr/hr/publikacije/ca sopisi/I2/odabrani-prijevodi/III/

\section{POSTOJI LI MOGUĆNOST POVEĆANJA UČINKOVITOSTI HRVATSKIH POREZNIH VLASTI?}

\author{
Dr.Sc. MiHAELA BRONIĆ" Č́lanaK" \\ DR.SG. VJEKOSLAV BRATIĆ* $\quad$ JEL: HII, H83 \\ DOI: $10.3326 /$ op. 24
}

\section{SAŽETAK}

Osnovni ciljevi ovog rada bili su utvrditi je li se u razdoblju 1997.-2012. poboljšala učinkovitost hrvatskih poreznih vlasti te identificirati na koje se načine u budućnosti može povećati. U proteklih petnaest godina troškovi su poreznih vlasti u Hrvatskoj u postotku BDP-a blago porasli, ali i dalje je taj udio iznad prosjeka država članica EU-a. Zbog toga postoji potreba njihova smanjenja, i to prvotno utvrđivanjem i ukidanjem "problematičnih" poreza od kojih se uz visoke troškove administriranja prikupi veoma malo prihoda. Роsebnu bi pažnju trebalo posvetiti i analizi i smanjenju rashoda za usluge poreznih vlasti (posebice troškova za računalne i usluge telefona, pošte i transporta). Najveći problem u istraživanju troškova poreznih vlasti u Hrvatskoj i dalje je nedostatak odgovarajućih i pouzdanih podataka u dužem vremenskom razdoblju, te bi hrvatske porezne vlasti trebale prikupljati i objavljivati što detaljnije podatke.

Ključne riječi: troškovi poreznih vlasti, oporezivanje, Hrvatska

Autori zahvaljuju anonimnim recenzentima na korisnim komentarima i sugestijama.

Primljeno: 26. svibnja 2014.

Prihvaćeno: 18. srpnja 2014.

Prijašnja verzija ovog rada predstavljena je na konferenciji Instituta za javne financije, Ekonomskog fakulteta u Zagrebu te Ekonomskog fakulteta u Rijeci Tax Reforms: Experiences and Perspectives koja je održana u Zagrebu 20. lipnja 2OI4.

Mihaela BRONIĆ

Institut za javne financije, Smičiklasova 2I, Ioooo Zagreb

e-mail: mihaela.bronic@ijf.hr

Vjekoslav BRATIĆ

Institut za javne financije, Smičiklasova 2I, IOooo Zagreb

e-mail: vjekoslav.bratic@ijf.hr 


\section{UVOD I PREGLED LITERATURE}

Ubiranje (naplata) poreza sve je samo ne besplatna, jer dovodi do određenih troškova koji se $u$ literaturi najčešće dijele na troškove poreznih vlasti (TPV) i troškove poreznih obveznika (TPO) (vidjeti npr. Sandford, Godwin i Hardwick, I989.). U ovom radu fokus analize bit će na troškovima poreznih vlasti, odnosno troškovima javnog sektora koji se javljaju pri provedbi (administriranju) postojećih poreznih zakona, uključujući i prijedloge za njihovu promjenu nastale u redovnoj djelatnosti tijela zaduženih za prikupljanje javnih prihoda (više u: Sandford, 1995., Sandford i sur, 1995.; Sandford i sur., 1989:3). Allers (1994:33) TPV definira kao troškove javnog sektora koji ne bi postojali da porez nije uveden, odnosno troškove koji bi nestali da se porez ukine.

U svijetu su raširena istraživanja ove teme ${ }^{\mathrm{I}}$ Evans (2003) analizirajući 6o studija TPV-a i TPO-a od 1980., zaključuje kako unutar zemalja koje su ih istraživale, TPV rijetko prelaze I\% prikupljenih prihoda, odnosno najčešce su ispod $\mathrm{i} \%$ te predstavljaju manji teret (u apsolutnim i relativnim iznosima) od TPO-a (više u: Evans, 2003:72). Od organizacija u istraživanju TPV-a najviše se ističe OECD koji je izdao pet publikacija s međunarodno usporedivim podacima o poreznim sustavima i poreznim upravama u 52 države (sve države OECD-a, EU-a i članice G2O) (OECD, 2004., 2006., 2009., 2OII. i 2OI3.). Prema posljednjoj OECD-ovoj publikaciji (20I3.) TPV se u postotoku BDP-a u razdoblju 2004.-II. među promatranim državama znatno razlikuju, a u jednoj trećini država iznose od o,I5 do 0,25\% BDP-a. Relativno nizak udio TPV-a u postotku BDP-a (odnosno manje od o,I2\%) uglavnom imaju države koje imaju mali porezni teret i/ili ne administriraju sve najvažnije poreze na državnoj, nego jedan dio tih poreza administriraju institucije na nižim razinama vlasti (npr. Čile, Estonija, Meksiko, SAD). Navodi se i kako je u manjem dijelu analiziranih zemalja vidljiv konstantan trend pada ovog udjela (npr. Australija, Danska, Francuska, Litva, Malezija, Meksiko, Nizozemska, Norveška, Rusija, Velika Britanija), ali bez objašnjenja zbog čega se to događa.

U Hrvatskoj su ovu temu prvi istraživali Ott i Bajo (200o.), zaključivši kako su TPV-i u četverogodišnjem razdoblju (1995.-99.) činili oko 0,55\% BDP-a; visoki su te zbog toga nude veliki prostor za moguće uštede. Naglasili su i kako bi bilo važno utvrditi TPV za svaki pojedini porez, ali i da je to $\mathrm{u}$ tom trenu bilo nemoguće jer se TPV ne prate po vrstama poreza, a da poseban problem predstavlja razdioba zajedničkih troškova na pojedine vrste poreza. Bratić i Pitarević (2004.) zaključuju kako su TPV u razdoblju od 1997.-200I. prosječno i dalje iznosili oko 0,55\% BDP-a, te da temeljni problem za istraživanje predstavlja točnost i relevantnost dostupnih podataka do kojih je teško doći, a često nisu ni javni niti dostupni. ${ }^{2}$ Blažić (2004.) iznosi kako ukupni troškovi oporezivanja u Hrvatskoj za razdoblje od lipnja 200I. do lipnja 2002. iznose oko 3,I3\% BDP-a, od čega TPV iznose O,47\%, a TPO 2,66\% BDP-a. Bratić i Šimović (2OIO.) analizirajući troškovnu učinkovitost porezne administracije u Hrvatskoj u razdoblju 2000.-07. i uspoređujući je sa zemljama OECD-a zaključuju kako ukupno gledajući hrvatske porezne vlasti (Porezna i Carinska uprava te Financijska policija) bilježe najlošije rezultate.

Cilj je ovog rada pokušati utvrditi je li se u razdoblju od 1997.-2002. efikasnost poreznih vlasti u Hrvatskoj poboljšala i što se može učiniti kako bi se ona povećala u budućnosti. Pretpostavljeno je kako je osnovni problem u istraživanju TPV-a u Hrvatskoj u dužem vremenskom razdoblju nedostatak

\footnotetext{
${ }^{\mathrm{I}}$ Npr. vidjeti Sandford, Godwin i Hardwick (1989.); Sandford i sur. (1995.); Evans, Pope i Hasseldine (200I.); Lignier i Evans (2012.) i OECD (2004., 2006., 2009., 2OII. i 20I3.).

${ }^{2}$ I istraživači u drugim tranzicijskim zemljama susreli su se s problemom nedostupnosti i nedovoljne kvalitete podataka za analizu. Primjerice, Vitek i Pubal (2002.) u analizi TPV-a u Češkoj, osim ovog problema, navode da čak i ako su podaci dostupni, oni postoje samo na agregiranoj razini, što često nije korisno prilikom izračuna TPV-a i TPO-a za pojedinu vrstu poreza.
} 
relevantnih informacija te da su se u proteklih petnaest godina u postotku BDP-a blago smanjili, ali su i dalje iznad prosjeka zemalja članica EU-a. OECD (2013:178) navodi kako se za utvrđivanje efikasnosti/efektivnosti poreznih vlasti često koristi pokazatelj "odnos troška i naplate” (koji se izračunava kao udio TPV-a u postotku od neto prihoda koje prikuplja porezna uprava). Smanjenje ovog pokazatelja tijekom godina, uz pretpostavku da se ništa drugo ne mijenja, trebalo bi ukazivati na smanjenje relativnih troškova (odnosno poboljšanje efikasnosti) i/ili povećanje prikupljenih poreza (odnosno poboljšanje efektivnosti). Međutim, OECD (2013.) ističe i kako ovaj pokazatelj treba uzimati s dozom opreza, jer na njega mogu utjecati i mnogi čimbenici koji nemaju veze s efikasnošću i/ili efektivnošću poreznih vlasti. I drugi autori ističu kako pri međunarodnim usporedbama TPV-a treba biti jako oprezan (vidjeti npr. Sandford, 1995:405; Sandford, 2000. i Evans, 2006.). Tako Sandford (2000:II9-I23) ističe kako je međunarodne usporedbe TPV-a koristeći spomenuti pokazatelj ("odnos troška i naplate") teško raditi iz razloga što je:

- izuzetno teško prikupiti podatke iz različitih država na standardiziranoj osnovi budući da se definicije TPV-a razlikuju, a mogu se razlikovati i prihodi koje porezne vlasti prikupljaju (npr. neke porezne vlasti prikupljaju socijalne doprinose i carine, a druge ne);

- demografski, politički, socijalni, ekonomski i pravni čimbenici u nekoj zemlji mogu znatno utjecati na pokazatelj "odnos troška i naplate" jer:

- se razlikuju porezne strukture (npr. u nekima je porezni prag za ulazak u sustav PDV-a nizak, a u drugima visok, a prikupljanje PDV-a od velikog broja malih obveznika povećava TPV);

- se razlikuje struktura poreznih obveznika (npr. više samozaposlenih obveznika povećava TPV);

- se razlikuju porezne stope (za zemlju s većim ukupnim poreznim prihodima u postotku BDP-a, odnosno većim poreznim teretom, moglo bi se očekivati i da ima niži pokazatelj omjera troška i naplate od zemlje koja je uvela slične poreze i u kojoj je porezni teret niži);

- dolazi do promjena u prihodima koje nisu povezane s promjenama poreznih stopa (npr. neuobičajene stope gospodarskog rasta ili inflacija); te

- na pokazatelj mogu utjecati mnogi drugi čimbenici (npr. uvođenje novih poreza).

I Sandford (2000:I23) i OECD (20I3,) naglašavaju kako pokazatelj “odnos troška i naplate” zanemaruje koliki su maksimalni potencijalni porezni prihodi koje bi porezne vlasti mogle prikupiti, što je jako važno, posebice pri međunarodnim usporedbama. Tako zemlje sa sličnim "odnosom troška i naplate" u stvarnosti mogu imati potpuno različitu efikasnost (mjerenu kao odnos između prikupljenih i makismalnih potencijalnih poreznih prihoda).

Stoga OECD (2013:I79-I82) ističe da je za međunarodne usporedbe efikasnosti poreznih vlasti primjereniji pokazatelj “odnos troškova i BDP-a” (koji se izračunava kao udio TPV-a u postotku BDP-a). Međutim i kod korištenja tog pokazatelja treba biti oprezan, jer na njega može utjecati niz čimbenika koji nemaju veze s efikasnošću poreznih vlasti (npr. velike investicije u nove tehnologije, troškovi povezani s primjenom novog poreza ili česte revizije BDP-a).

Unatoč svim ovim nedostacima TPV-i se izračunavaju i pokušavaju usporediti s ostalim zemljama s ciljem utvrđivanja razlika u TPV-u među zemljama kako bi se dalje za svaku pojedinu zemlju analizirale i istraživale razlike koje mogu, ali i ne moraju, imati veze s efikasnošću poreznih administracija (Sandford, 2000:I37). Upravo zbog toga u nastavku će biti objašnjena metodologija izračuna i istraživanja TPV-a u 
Hrvatskoj, nakon čega će biti uspoređeni TPV-i u Hrvatskoj i u zemljama EU-a. Na kraju slijede zaključci o mogućim načinima povećanja učinkovitosti hrvatskih poreznih vlasti.

\section{METODOLOGIJA I PODAGI}

Već je ranije rečeno kako se TPV-i u Hrvatskoj odnose na troškove tri institucije zadužene za prikupljanje poreza i carina (PU, CU i FP ${ }^{3}$ ). TPV-i se uglavnom financiraju iz državnog proračuna, a jednim malim dijelom i iz vlastitih prihoda te tri institucije. Ott i Bajo (200o.) napominju kako bi za potpuniju analizu ukupnih TPV-a u Hrvatskoj trebalo uključiti i troškove institucije koja prikuplja i evidentira poreze i carine (Zavod za platni promet (ZAP) do 200I., odnosno Financijska agencija (FINA) od 2002.) te troškova sudova koji obrađuju pojedinačne porezne i carinske slučajeve. ${ }^{4}$

Nažalost, u ovom istraživanju nije bilo moguće doći do podataka o troškovima ZAP-a, FINA-e i navedenih sudova, jer javno dostupnih podataka nema. Na zahtjev za pravo na pristup informacijama Ministarstvo pravosuđa i FINA odgovorili su kako ne posjeduju tražene podatke ili da će podatke naknadno poslati (ali to nikad nisu učinili niti su uopće na upit odgovorili). Iz izvješća FINA-e jasno je da njen Centar za podršku sustavu riznice na temelju ugovora obavlja određene poslove za potrebe PU-a te račun, umjesto PU, ispostavlja Ministarstvu financija (MF). ${ }^{5}$ Stoga bi u budućnosti trebalo detaljnije istražiti koje sve poslove FINA obavlja za PU i te troškove, budući ih ne plaća PU, uključiti u TPV. Trenutno je to nemoguće, jer se prikazuju unutar proračuna MF-a i nisu jasno razgraničeni od ostalih troškova.

Osim toga, Sandford (2000:II7) i Evans (2006:2-3) navode i druge troškove koje bi trebalo uključiti u TPV (npr. troškove parlamenta povezane s donošenjem poreznih zakona). U ovom istraživanju nisu razmatrani niti ovi troškovi te bi ih u budućnosti bilo korisno istražiti.

U radu se koriste izvještaji MF-a te PU i CU. ${ }^{6}$ Prema ekonomskoj klasifikaciji primijenjenoj u hrvatskom državnom proračunu, u TPV su uključeni rashodi/troškovi poslovanja (npr. za zaposlene, utrošeni materijal, energiju i računalne usluge) te troškovi za nabavu kapitalnih sredstava (npr. zgrade

\footnotetext{
${ }^{3}$ Financijska policija (FP) postojala je od 28. prosinca 1992. do 3I. prosinca 200I., a ukinuta je u razdoblju od I. siječnja 2002. do 3I. prosinca 2005. Ponovno je osnovana I. siječnja 2006. da bi 6. ožujka 20I2. bila opet ukinuta. Rad FP-a regulirao je Zakon o financijskoj policiji (NN I77/O4, 55/II i 25/I2). Prema tomu je Zakonu FP bila zadužena za financijski nadzor zakonitosti, pravilnosti, i pravodobnosti obračuna, prijava i uplata proračunskih prihoda i naknada propisanih posebnim zakonima (posebice onih koji se odnose na trošarine, doprinose za socijalno osiguranje, koncesije i sporazume o zakupu.

Prema Zakonu o carinskoj službi (do 200I. NN 53/9I i 06/93, u razdoblju 200I.-O9. NN 67/oI, u razdoblju 2009.-I3. NN 83/o9, 49/II i 34/I2, a od 2013. NN 68/I3 i 30/I4) temeljne zadaće CU-a odnosile su se na utvrđivanje, naplatu i nadzor carinskih davanja, trošarina, posebnih poreza, PDV-a, drugih javnih davanja i javnopravnih naknada kao i osiguravanje pravilne primjene carinskih i drugih propisa koji se odnose na unos, iznos, provoz, prijenos, skladištenje i drugo raspolaganje s robom koja podliježe mjerama carinskog nadzora.

${ }^{4}$ Misli se na troškove upravnih sudova koji sude u prvom stupnju za pojedinačne porezne i carinske slučajeve (u Zagrebu, Splitu, Rijeci i Osijeku), te troškove Visokog upravnog suda u Zagrebu koji sudi u drugom stupnju (po žalbama na prvi stupanj). Općim poreznim zakonom propisani su pravni lijekovi u poreznom postupku (čl. I59.-I7I., Opći porezni zakon, NN I47/O8, I8/II, 78/I2, I36/12 i 73/13).

${ }^{5}$ FINA obavlja slijedeće poslove vezano uz prihode za koje PU vodi analitičku evidenciju: (I) podršku sustavu evidentiranja i rasporeda javnih prihoda, te (2) ostale poslove za PU (evidentiranje i naplata naknade od jedinica lokalne i područne (regionalne) samouprave u slučaju kada PU za te jedinice obavlja poslove utvrđivanja, evidentiranja, nadzora, naplate i ovrhe određenih lokalnih prihoda; objedinjavanje i dostava podataka iz izvadaka računa o kojima PU vodi analitičku evidenciju; primitak, provjera ispravnosti i unos naloga/zahtjeva za povrat javnih prihoda te preknjiženja javnih prihoda s računa o kojima PU vodi analitičke evidencije (više u: FINA, 2OI2.).

${ }^{6}$ Korišteni su godišnji izvještaji o izvršenju državnog proračuna RH u razdoblju 200o.-I2. (Ministarstvo financija, 200o.-I2.); podaci o izdacima PU-a u odnosu na financijski plan proračuna u razdoblju 1995--2006. (Porezna uprava, I995.-2006.); izvještaji o prihodima i rashodima, primicima i izdacima u razdoblju 2002.-I2. PU (Porezna uprava, 2002.-I2.), izvješća o broju zaposlenih, ukupnim godišnjim vlastitim prihodima CU-a i ukupnim godišnjim troškovima CU-a financiranim iz vlastitih sredstava CU-a za razdoblje 1997--2012. (Carinska uprava, I997.-2012.) te izvještaji o prihodima i rashodima, primicima i izdacima za razdoblje 2005.-I2. CU (Carinska uprava, 2005.-12.). Podaci iz ovih dokumenata nisu uvijek pouzdani jer se npr. brojke za istu vrstu podataka međusobno razlikuju, posebice za razdoblje do 2004., zbog čega su autori morali odabrati koje će brojke koristiti u analizi.
} 
i uredska oprema). No, korištena izvješća često nisu bili adekvatna za sve željene analize, zbog čega je još uvijek nemoguće TPV utvrditi za svaki pojedini porez. Osim toga, bilo bi zanimljivo doznati točan iznos poreznih prihoda koje prikupljaju PU i CU, no to je bilo nemoguće jer nismo raspolagali podacima o iznosu PDV-a na uvoz koji prikuplja CU.

Unatoč svemu navedenome, ovo je prvo istraživanje za Hrvatsku koje u TPV od 200I. i 2002. uključuje i troškove povezane s prikupljanjem doprinosa za socijalna osiguranja. Te doprinose su do 200 . najvećim dijelom prikupljale zasebne institucije (Hrvatski zavod za mirovinsko osiguranje - HZMO, Hrvatski zavod za zdravstveno osiguranje - HZZO te Hrvatski zavod za zapošljavanje - HZZ) koje su imale status izvanproračunskih fondova. U to se vrijeme njihovi troškovi (kao i prihodi od doprinosa za socijalna osiguranja) nisu prikazivali u državnom proračunu. Troškove tih institucija u dosadašnjim istraživanjima nije bilo moguće uključiti u TPV, jer iz dostupnih podataka nije jasno koliki se dio trošio na prikupljanje socijalnih doprinosa, a koliki na razne naknade koje te institucije isplaćuju (npr. za mirovine, naknade bolovanja i zdravstvenu zaštitu). Budući da se u prijašnjim istraživanjima troškovi tih institucija nisu uključivali u ukupne TPV-e, iz istog razloga i prihodi od socijalnih doprinosa nisu bili uključeni u ukupne prihode koje prikupljaju porezne vlasti.

Premda je i do 20oI. obavljala određeni, ali manji dio poslova vezanih uz doprinose za socijalna osiguranja $^{8}$, u srpnju 200I. PU postala je odgovorna i preuzela sve poslove vezane uz te doprinose, uključujući i utvrđivanje, evidentiranje, naplatu, nadzor, ovrhu i pokretanje te vođenje prekršajnog postupka (Zakon o Poreznoj upravi, NN 67/oI). Zbog toga su u troškove PU (dakle i u TPV-u) od I. srpnja 200I. uključeni troškovi vezani za doprinose za mirovinsko osiguranje, a od I. siječnja 2002. i troškovi doprinosa za zapošljavanje te doprinosa za zdravstveno osiguranje. Istovremeno su i prihodi vezani uz prikupljanje tih doprinosa uključeni u prihode koje prikupljaju porezne vlasti.

U nastavku će biti prikazana analiza ključnih pokazatelja (ne)učinkovitosti hrvatskih poreznih vlasti, koji će biti uspoređeni s prosjekom zemalja članica EU-a, a potom će se pokušati utvrditi koje bi troškove hrvatske porezne vlasti mogle/trebale smanjiti.

\section{ANALIZA TPV-A U HRVATSKOJ U RAZDOBLJU I997.-20I2.}

Kao što je vidljivo iz grafikona I., ukupni TPV u Hrvatskoj 20I2. u odnosu na 1997. pali su za oko Io\%, i to s o,48\% na o,44\% BDP-a. Najveći udio TPV-a u BDP-u zabilježen je 1999. (o,58\%).

Najveće se smanjenje TPV-a dogodilo 200I. i 2002. kada dolazi do istovremenog rasta BDP-a i smanjenja TPV-a u apsolutnom iznosu. U razdoblju 2005.-Io. ovaj udio ponovno raste, da bi nakon 20Io. i razdoblja pogoršavanja ekonomske situacije lagano padao. Kao rezultat toga Hrvatska je 2012. trošila o,44\% BDP-a za administriranje poreznih i carinskih zakona. Kako bismo utvrdili jesu li ukupni TPV-i u Hrvatskoj visoki ili ne, uz sva ograničenja i nedostatke (različit obuhvat i metodologija), pokušat ćemo ih usporediti s prosjekom EU-a.

\footnotetext{
${ }^{7}$ Upravo zbog uključivanja troškova vezanih uz socijalne doprinose u TPV u ovoj analizi, ukupni TPV-i nisu u potpunosti usporedivi u razdoblju prije i poslije 200I./2002.

${ }^{8}$ Na primjer, nadzor pravilnosti i pravodobnosti obračuna i uplate doprinosa (vidjeti Zakon o poreznoj upravi, NN 7I/99).
} 
GRAFIKON I.

TPV u Hrvatskoj, u \% BDP-a, 1997.-20I2.

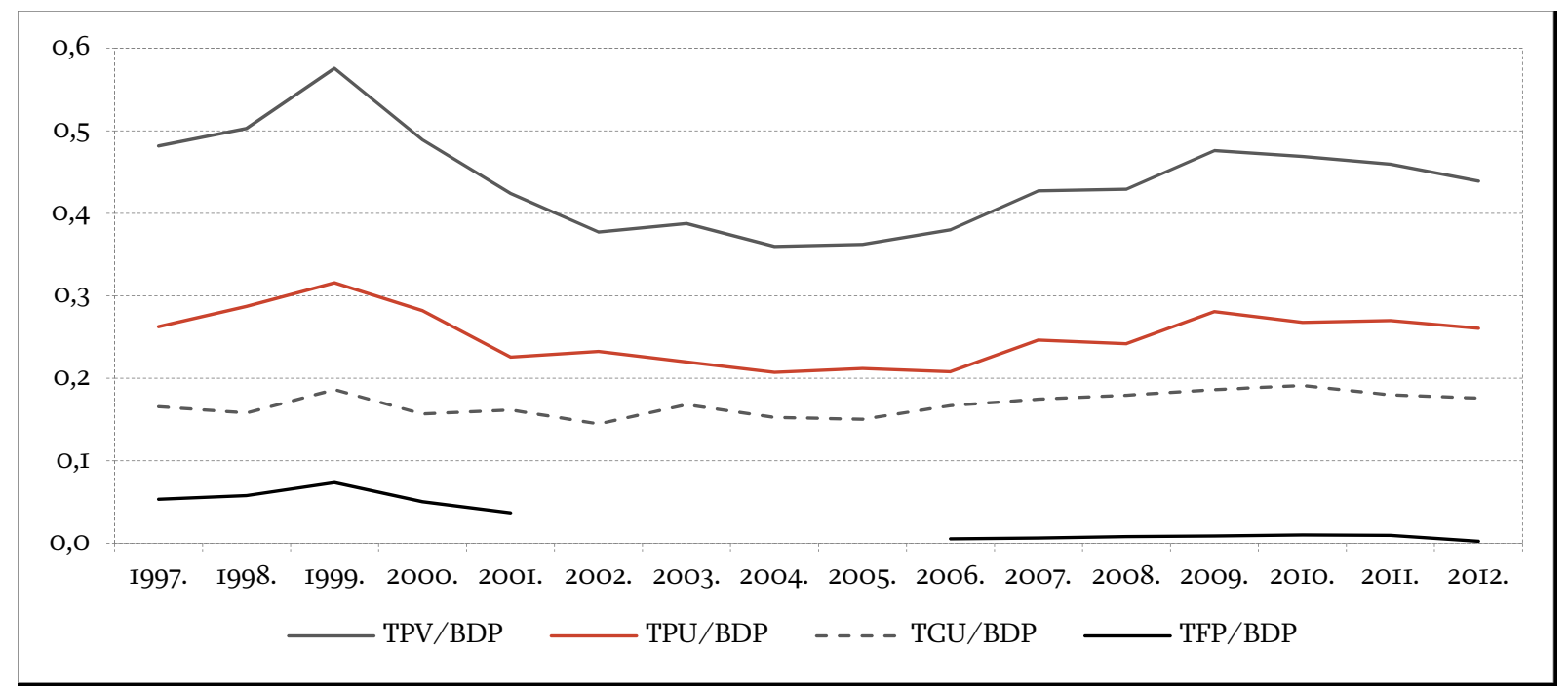

TPU - troškovi PU; TCU - troškovi CU; TFP - troškovi FP.

Izvor: Ministarstvo financija (2000.-I2.); Porezna uprava (I995.-2006., 2002.-I2.), Carinska uprava (I997.-20I2., 2005.-I2.).

\section{GRAFIKON 2.}

Usporedba TPV-a u Hrvatskoj i EU, u \% BDP-a, 2005.-II.

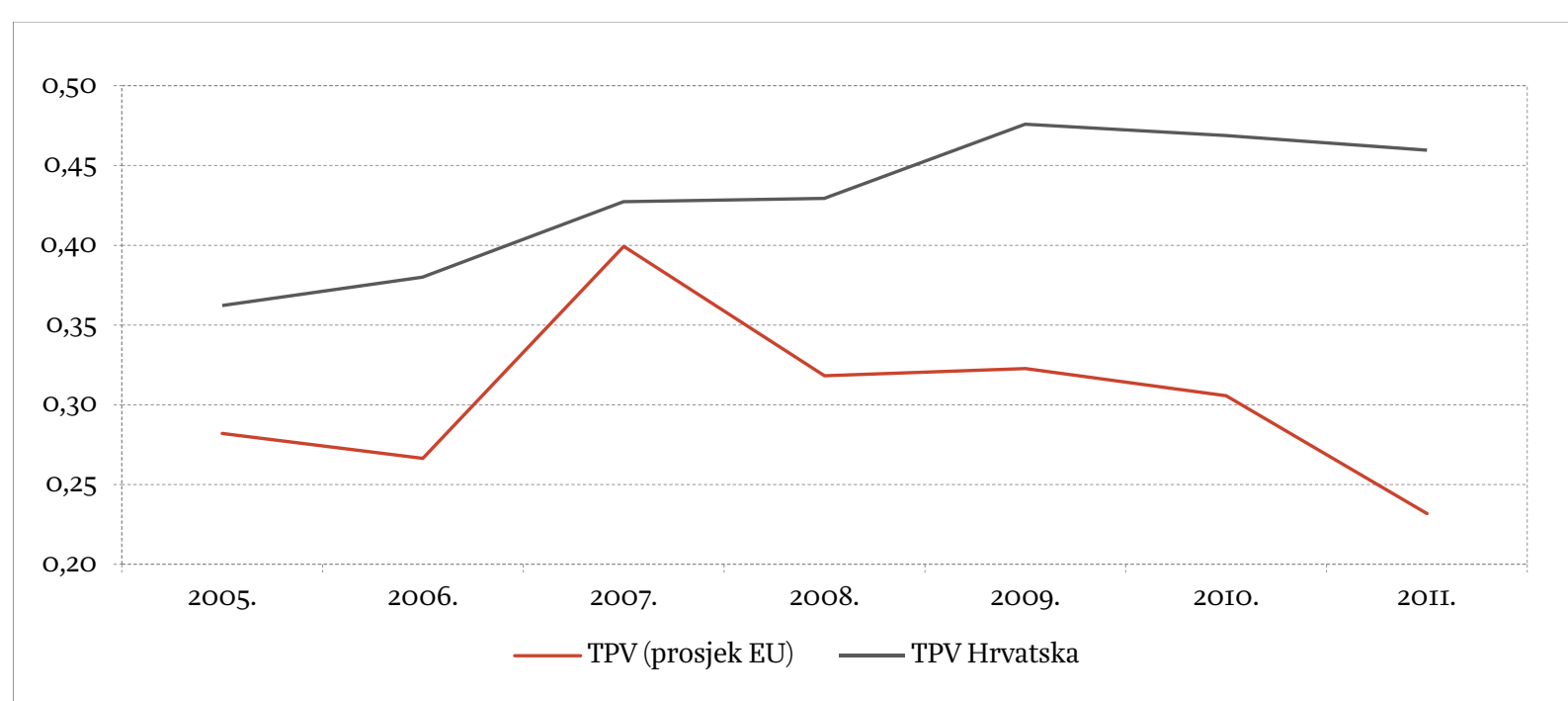

Izvor: OECD (2013.), MF (2000.-I2.); Porezna uprava (I995.-2006., 2002.-I2.), Carinska uprava (I997.-2012., 2005.-I2.).

Kao što je iz grafikona 2. vidljivo, TPV-i kao postotak BDP-a u Hrvatskoj u razdoblju 2005.-II. viši su od prosjeka zemalja članica EU-a. ${ }^{9}$ Dodatak I. prikazuje udio TPV-a u BDP-u po pojedinim zemljama članicama za razdoblje 2005.-I2. Podaci o TPV-ima za sve zemlje članice prije 2005. nisu bili dostupni, a i iz dostupnih podataka nakon 2005. nije u potpunosti jasno što sve pojedine članice uključuju u TPV. Zanimljivo je da su 2007. TPV-i u Hrvatskoj bili gotovo jednaki prosjeku EU-a, ali su u razdoblju nakon 2007. porasli (na o,46\% BDP-a u 20II.), dok su u EU snažno pali (na o,23\% BDP-a u 2OII.).

\footnotetext{
${ }^{9} \mathrm{Ne}$ treba previdjeti činjenicu i kako se u tome razdoblju mijenjao i broj zemalja članica EU-a, jer su se 2007. Bugarska i Rumunjska pridružile EU.
} 


\section{GRAFIKON 3.}

TPV u Hrvatskoj, u \% prikupljenih poreznih prihoda, I997.-20I2.*

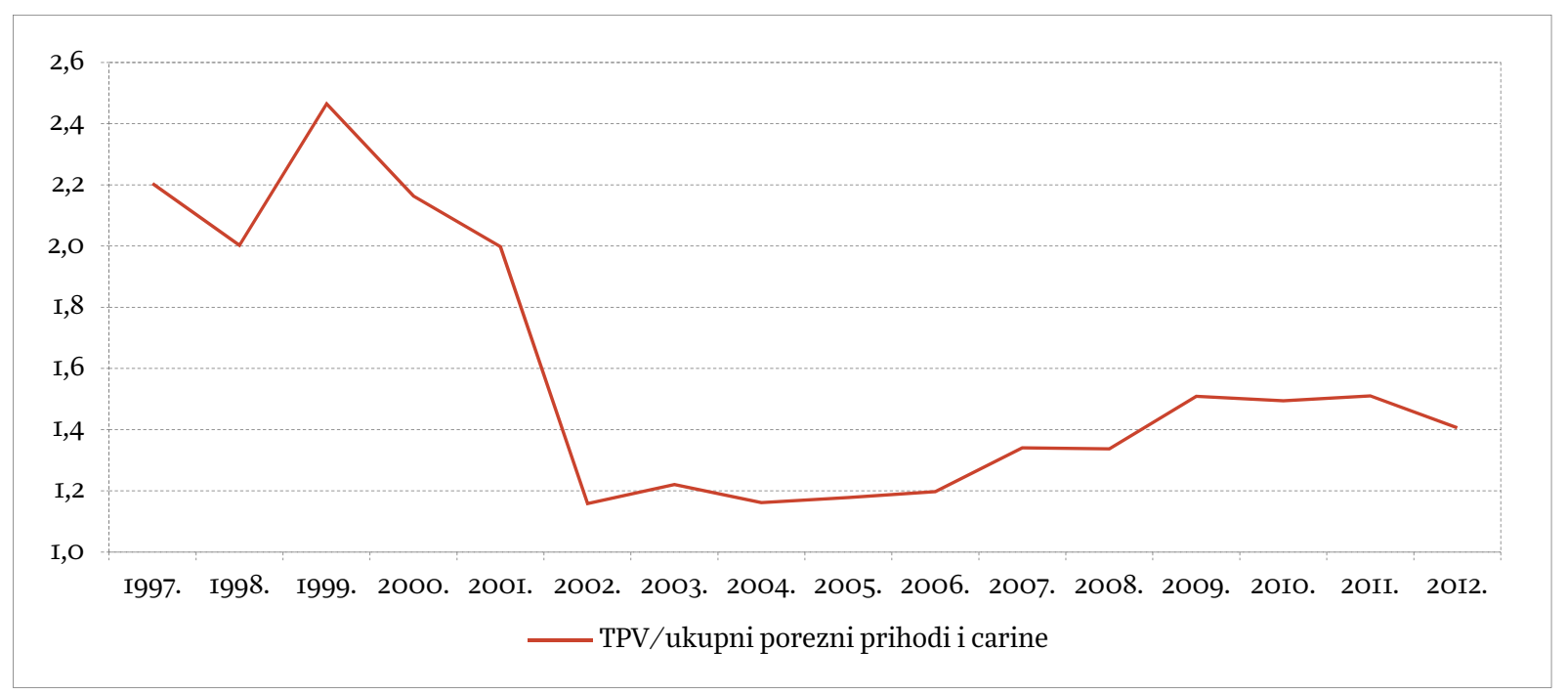

*Za potrebe ove analize "prikupljeni porezni prihodi" predstavljaju porezne i carinske prihode državnog proračuna. Izvor: Ministarstvo financija (2000.-I2.), Porezna uprava (I995.-2006., 2002.-I2.), Carinska uprava (I997.-2OI2., 2005.-I2.).

TPV-i u postotku prikupljenih poreznih prihoda u Hrvatskoj značajno se smanjuju 200I. i 2002. (s 2,I6\% u 2000. na I,I4\% u 2002., grafikon 3. $)^{\text {ID }}$. Najjednostavnije rečeno to znači da su se za prikupljanje Ioo kuna poreznih i carinskih prihoda 2002. trošile I,I4 kune. Zasigurno je najvažniji razlog ovako velikog smanjenja TPV-a u postotku ukupno prikupljenih poreznih prihoda u 200I. i 2002. ranije objašnjeno uključivanje socijalnih doprinosa $u$ ukupne prikupljene prihode koje prikupljaju porezne vlasti. Socijalni su doprinosi u Hrvatskoj, nakon PDV-a, drugi po izdašnosti izvor poreznih prihoda. Primjerice, u razdoblju 200o.-I2. prosječno se od socijalnih doprinosa prikupljalo oko $34 \%$ poreznih prihoda (uključujući i carine) na razini opće države (vidi dodatak 2.). Ne treba zanemariti ni kako je $\mathrm{u}$ tome razdoblju došlo do rasta BDP-a, smanjenja TPV-a u apsolutnim iznosima te ukidanja FP-a. Nakon 2002. TPV blago rastu te 2012. iznose 1,4\% ukupno prikupljenih poreznih prihoda.

Moguće je zaključiti kako bi TPV u Hrvatskoj trebalo preispitati i po mogućnosti smanjiti. Zbog toga bi prvi korak u tome smjeru moglo biti identificiranje i preispitivanje tzv. problematičnih (eng. nuisance) poreza kojima se prikuplja jako malo prihoda, a mogu imati visoke TPV i TPO (kao što je to slučaj u drugim zemljama, vidjeti: Chittenden, Foster i Sloan, 20I0:159). Puno bi efikasnije bilo kada bi se neki od tih poreza u potpunosti ukinuli. Iako postoji potreba detaljnije analize, na prvi pogled čini se kako bi u Hrvatskoj u kategoriju takvih, problematičnih poreza mogli spadati: određene vrste poreza na imovinu (npr. porez na korištenje javnih površina i porez na kuće za odmor), porezi na potrošnju, izuzev PDV-a i trošarina (npr. porez na tvrtku ili naziv) i/ili ostali određeni iznosom manji porezi (vidjeti dodatak 2.). Drugim riječima, preispitivanje upravo tih problematičnih poreza treba biti prvi korak u analizi TPV-a. Grafikon 4. uspoređuje TPV u Hrvatskoj u postotku prikupljenih prihoda s prosjekom EU-a.

\footnotetext{
${ }^{\text {Io }}$ Neporezni prihodi državnog proračuna (kao što su porez na imovinu, razne administrativne naknade i kazne) nisu uključeni u ukupne prihode koje prikupljaju PU, CU i FP jer nismo raspolagali informacijom koliko te institucije pojedinačno sudjeluju u administriranju tih prihoda. To bi također trebalo istražiti u budućim analizama.

Osim toga, kako PU prikuplja poreze i za neke lokalne jedinice, naplaćujući im naknadu u iznosu od 5\% prikupljenih poreznih prihoda, željeli smo saznati broj općina, gradova i županija za koje PU prikuplja prihode kako bi uopće spoznali kolike bi iznose tih poreza trebalo uključiti u prihode koje prikuplja PU. No, na taj naš zahtjev PU nije odgovorila.
} 


\section{GRAFIKON 4.}

TPV u Hrvatskoj i EU, u \% prikupljenih prihoda, 2005.-II.*

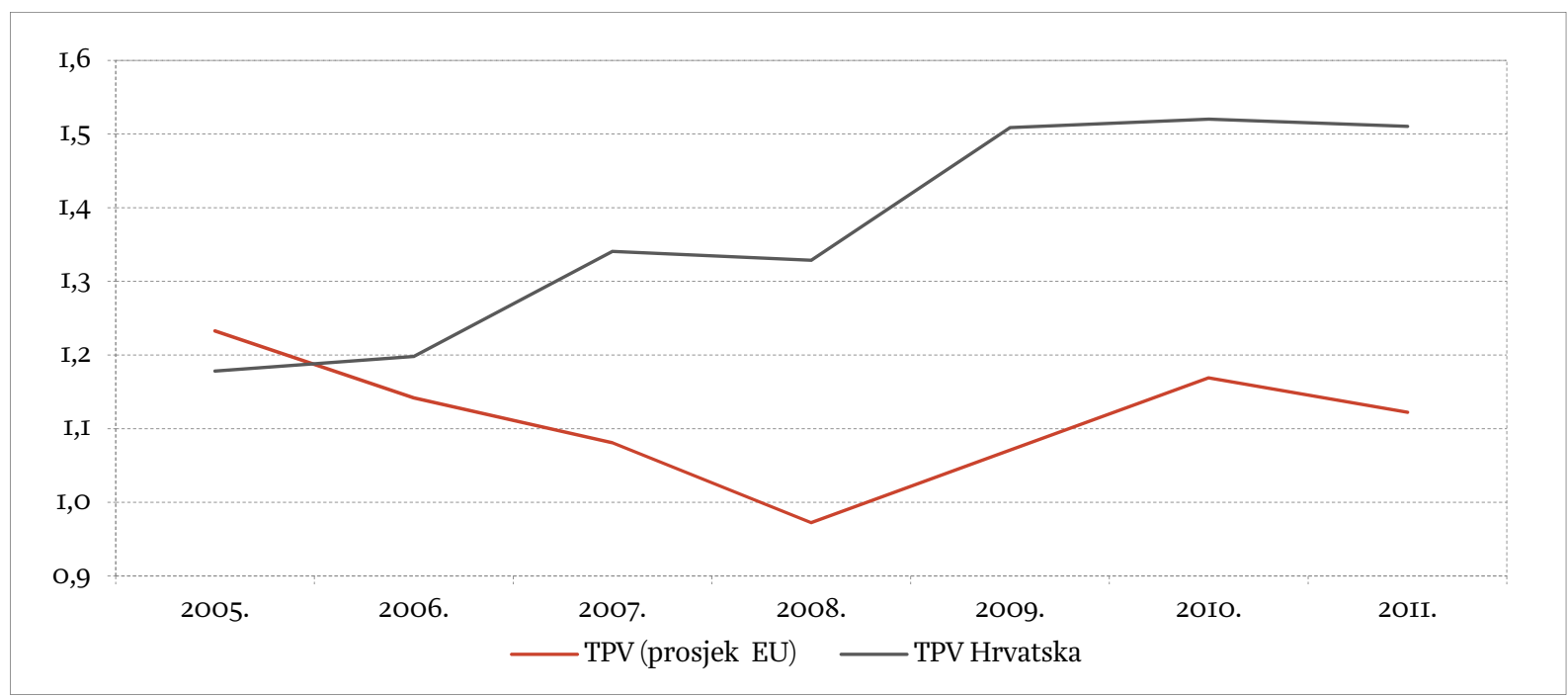

*Za potrebe ove analize "prikupljeni prihodi" predstavljaju porezne i carinske prihode državnog proračuna.

Izvor: OECD (2013.), Ministarstvo financija (2000.-I2.), Porezna uprava (I995.-2006., 2002.-I2.), Carinska uprava (I997.-2012., 2005.-I2.).

Godine 2005. TPV-i u Hrvatskoj iznose oko 1,2\% prikupljenih prihoda i bili su gotovo jednaki prosjeku EU-a. Međutim, nakon 2005. prisutan je obrnuti trend jer TPV-i u Hrvatskoj konstantno rastu da bi 20II. iznosili oko 1,5\% prikupljenih prihoda, dok prosječni TPV-i u EU padaju da bi 20II. iznosili I,I\% prikupljenih prihoda. Kako bismo odgovorili na pitanje zašto su hrvatske porezne vlasti relativno neučinkovite u odnosu na prosjek EU-a u nastavku istražujemo strukturu TPV-a u Hrvatskoj.

\section{GRAFIKON 5.}

TPV po institucijama, u mil. kuna, 1997.-20I2.

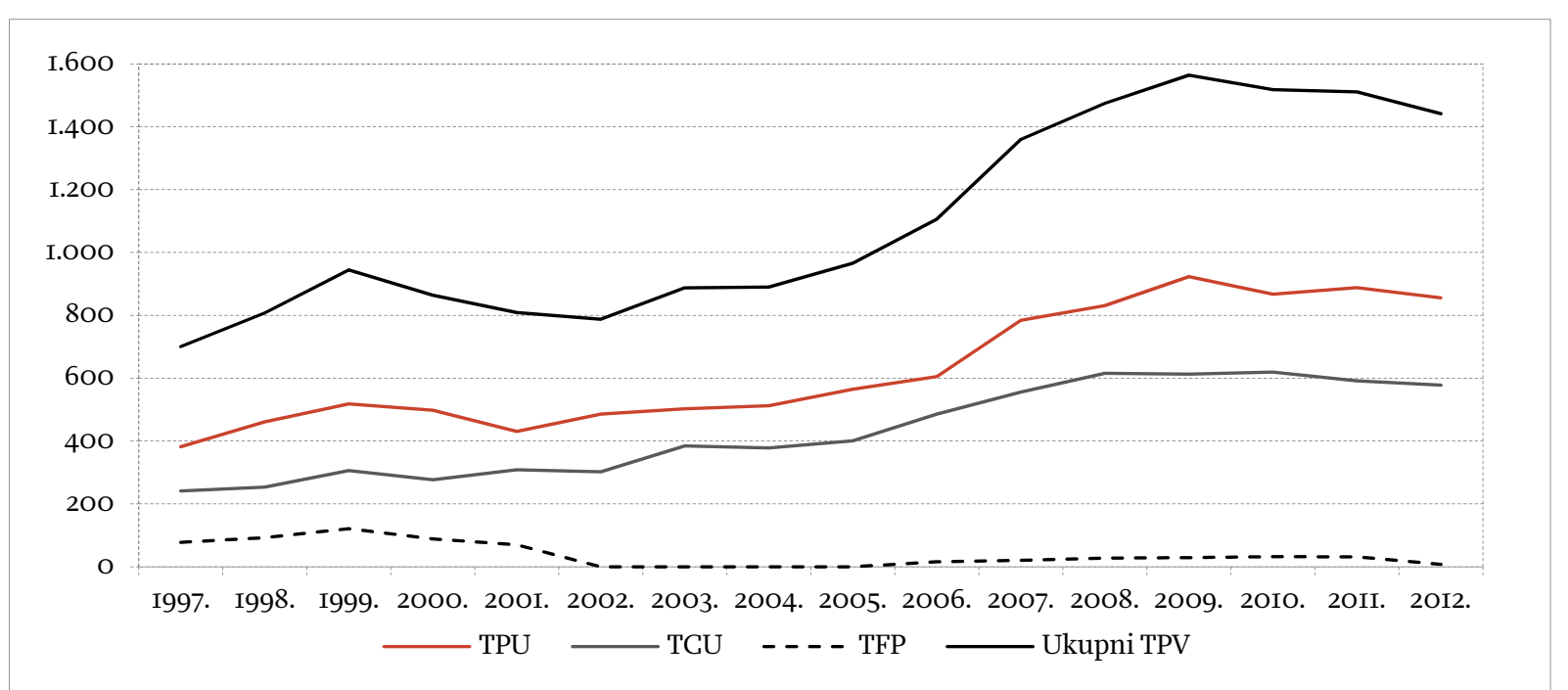

TPU - troškovi PU, TCU - troškovi CU, TFP - troškovi FP.

Izvor: Ministarstvo financija (2000.-I2.), Porezna uprava (I995.-2006., 2002.-I2.), Carinska uprava (I997.-2OI2., 2005.-I2.).

Ukupni TPV-i u Hrvatskoj su se u razdoblju 1997--2012. u apsolutnom iznosu više nego udvostručili (s oko o,7 na oko I,4 milijarde kuna). Od 1997. do 2009. troškovi PU i CU u apsolutnim iznosima uglavnom rastu (osim, 2000., 200I. i 2002.), a nakon 2009. blago se smanjuju (grafikon 5). U razdoblju 2004.-I2. ukupni TPV rastu za oko 60\% (s oko o,9 na oko I,4 milijarde kuna). U čitavom razdoblju 
1997.-20I2. troškovi PU-a čine 50-60\% ukupnih TPV-a, dok ostatak uglavnom čine troškovi CU-a (troškovi FP-a su gotovo zanemarivi).

\section{TABLIGA I.}

Struktura ukupnih TPV-a, 2004.-I2.*

2004. 2005. 2006. 2007. 2008. 2009. 2010. 2011. 2012. Prosjek

\begin{tabular}{lccccccccccccc} 
Trošak za zaposlene & 80 & 72 & 74 & 67 & 66 & 63 & 64 & 64 & 64 & 68 \\
\hline $\begin{array}{l}\text { Trošak za materijal i } \\
\text { energiju }\end{array}$ & 4 & 5 & 5 & 4 & 4 & 4 & 4 & 4 & 4 & 4 \\
\hline Trošak za usluge & I2 & I8 & I6 & 23 & 25 & 29 & 27 & 27 & 29 & 23
\end{tabular}

Ostali nespomenuti $\quad 0 \quad$ I

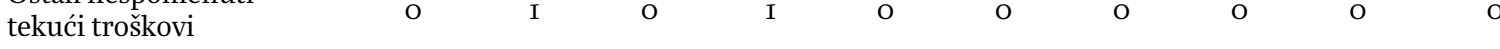

\begin{tabular}{llllllllllll}
$\begin{array}{l}\text { Troškovi za nabavu } \\
\text { nefinancijske imovine }\end{array}$ & 3 & 5 & 5 & 6 & 5 & 5 & 5 & 5 & 3 & 5 \\
\hline Ukupni TPV & IOO & IOO & IOO & IOO & IOO & IOO & IOO & IOO & IOO & -
\end{tabular}

* Analizirani su samo TPV financirani iz državnog prorčauna. Manji iznosi TPV-a koje su PU, CU i FP financirali vlastitim sredstvima nisu uključeni zbog nedostatka detaljnih podataka.

Izvor: Ministarstvo financija (2000.-I2.).

Analiza financijskih izvješća za razdoblje 2004.-I2. pokazala je kako su najveći udio imali troškovi za zaposlene i troškovi za usluge, koji zajedno čine oko 90\% ukupnih TPV-a (tablica I.).

\section{TABLICA 2.}

TPV, u mil. kuna, 2004-20I2.*

\begin{tabular}{|c|c|c|c|c|c|c|c|c|c|c|}
\hline & 2004. & 2005 & 2006. & 2007 & 2008 & 2009. & 2010. & 2011. & 2012. & $\begin{array}{c}\text { 2012./2004. } \\
(\text { promjena u \% })\end{array}$ \\
\hline Trošak za zaposlene & $63 I$ & 668 & 775 & 898 & $97 \mathrm{I}$ & 975 & $97 \mathrm{I}$ & 966 & $92 I$ & 46 \\
\hline $\begin{array}{l}\text { Trošak za materijal i } \\
\text { energiju }\end{array}$ & 36 & 43 & 48 & $5 \mathrm{I}$ & 55 & 56 & 57 & 54 & 57 & 60 \\
\hline Trošak za usluge & 96 & 165 & 167 & 316 & 369 & 446 & $4 \mathrm{IO}$ & 409 & 420 & 336 \\
\hline $\begin{array}{l}\text { Ostali nespomenuti } \\
\text { tekući troškovi }\end{array}$ & 3 & 5 & 4 & 7 & 6 & 4 & 5 & 4 & 4 & I4 \\
\hline $\begin{array}{l}\text { Troškovi za nabavu } \\
\text { nefinancijske imovine }\end{array}$ & 26 & 43 & 55 & 78 & 70 & 78 & 73 & 75 & 38 & 42 \\
\hline Ukupni TPV & 793 & 924 & I.049 & I.35I & I. 472 & I.56o & I.5I6 & I.5O8 & I.439 & - \\
\hline
\end{tabular}

* Podaci se odnose isključivo na troškove financirane iz državnog proračuna. Manji iznosi TPV-a koje su PU, CU i FP financirali vlastitim sredstvima nisu uključeni zbog nedostatka detaljnih podataka.

Izvor: Ministarstvo financija (200o.-I2.).

Kao što pokazuje tablica 2., u analiziranom razdoblju 2004.-I2. troškovi za zaposlene i usluge kontinuirano su rasli (troškovi za zaposlene porasli su za 46\%, tj. sa 63I na 92I milijun kuna, a troškovi za usluge za više od 330\%, tj. s 96 na 420 milijuna kuna). Zbog svega navedenog u nastavku su detaljnije analizirani troškovi za zaposlene i troškovi za usluge. 
GRAFIKON 6.

Troškovi za plaće u Hrvatskoj i EU, u \% TPV-a, 1997.-20II.

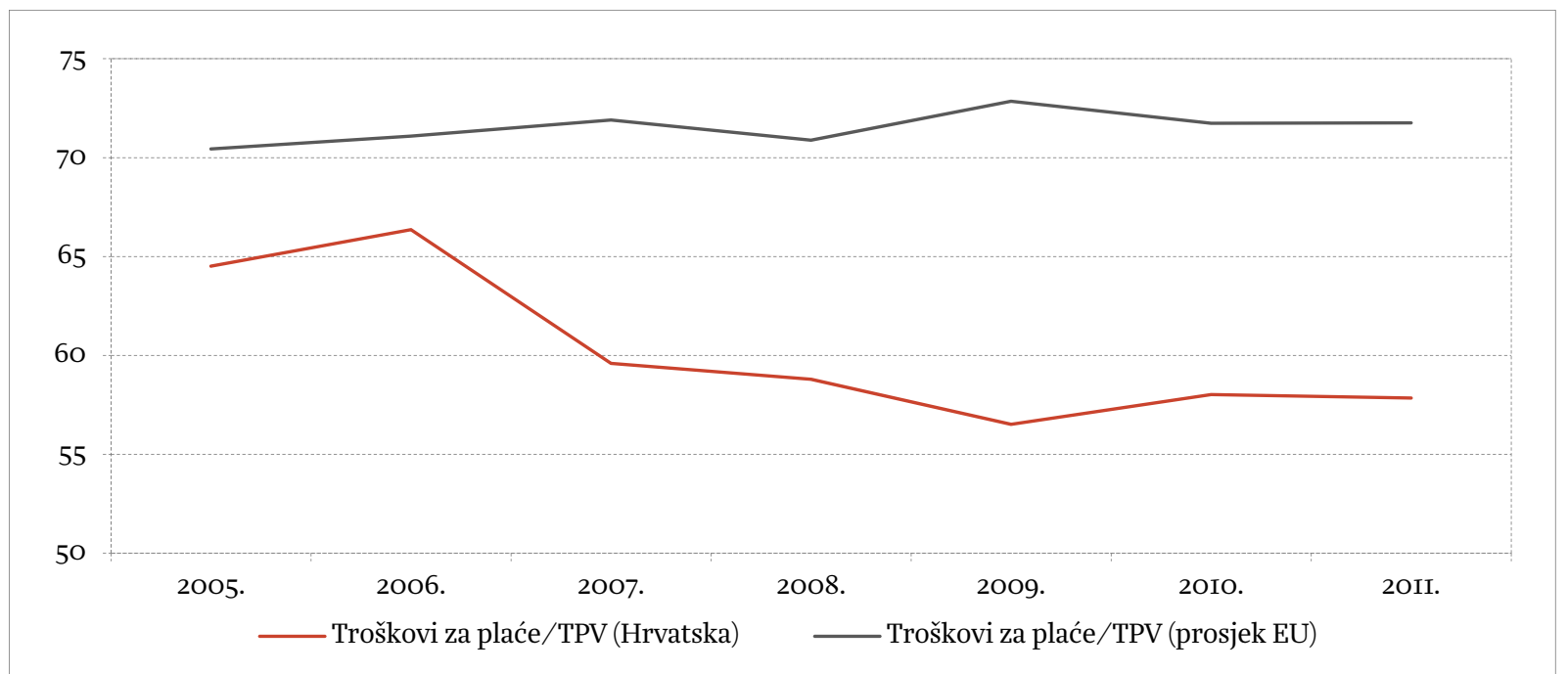

*Za Hrvatsku se podaci odnose isključivo na troškove financirane iz državnog proračuna. Manji iznosi TPV-a koje su PU, CU i FP financirali vlastitim sredstvima nisu uključeni zbog nedostatka detaljnih podataka.

Izvori: OECD (2013.), Ministarstvo financija (2000.-I2.), Porezna uprava (I995.-2006., 2002.-I2.), Carinska uprava (I997.-2012., 2005.-I2.).

Za zemlje članice EU-a bili su dostupni samo podaci o troškovima za plaće. Prema dostupnim podacima u razdoblju 2005.-II. udio troškova za plaće u TPV-u u Hrvatskoj ${ }^{\text {II }}$ bio je nešto niži od prosjeka zemalja članica EU-a. U razdoblju 2005.-II. prosjek tog udjela u EU iznosio je oko 70\% ukupnih TPV-a. I Sandford (2000:II8) navodi kako se u drugim istraživanjima pokazalo da troškovi za zaposlene imaju najveći udio u ukupnim TPV-ima i kako najčešće čine oko tri četvrtine TPV-a.

TABLICA 3.

Struktura troškova usluga, 2004.-I2., u \% ukupnih troškova za usluge*

\begin{tabular}{|c|c|c|c|c|c|c|c|c|c|c|}
\hline Trošak za & 2004. & 2005. & 2006. & 2007. & 2008. & 2009. & 2010. & 2011. & 2012. & $\begin{array}{r}\text { Prosjek } \\
2004 .-12 .\end{array}$ \\
\hline $\begin{array}{l}\text { usluge telefona, pošte } \\
\text { i prijevoza }\end{array}$ & 50 & $6 I$ & 46 & 27 & 25 & 27 & 24 & $2 \mathrm{I}$ & I8 & 33 \\
\hline $\begin{array}{l}\text { usluge tekućeg i } \\
\text { investicijskog održavanja }\end{array}$ & II & 8 & I3 & 9 & 8 & 7 & II & 3 & 7 & 9 \\
\hline komunalne usluge & I6 & 13 & $\mathrm{I} 2$ & 7 & 7 & 6 & 7 & 2 & 2 & 8 \\
\hline zakupnine i najamnine & 7 & 6 & 8 & 6 & 5 & 4 & 6 & 7 & 7 & 6 \\
\hline $\begin{array}{l}\text { intelektualne i osobne } \\
\text { usluge }\end{array}$ & 2 & 2 & 3 & 4 & 7 & I7 & 8 & 4 & 5 & 6 \\
\hline računalne usluge & 3 & 3 & 3 & 37 & 40 & 34 & 38 & 52 & $5 \mathrm{I}$ & 29 \\
\hline ostale usluge & II & 8 & I5 & IO & 7 & 5 & 6 & II & IO & 9 \\
\hline Ukupno & IOO & IOO & IOO & IOO & IOO & IOO & IOO & IOO & IOO & - \\
\hline
\end{tabular}

* Podaci se odnose isključivo na troškove financirane iz državnog proračuna. Manji iznosi TPV-a koje su PU, CU i FP financirali vlastitim sredstvima nisu uključeni zbog nedostatka detaljnih podataka.

Izvor: Ministarstvo financija (2000.-I2.).

Iz tablice 3. vidljivo je kako bi posebnu pažnju u analizama trebalo posvetiti analizi troškova za računalne (IT) usluge (koji rastu s 3\% 2004. na 5I\% 20I2. ukupnih troškova za usluge). Zanimljivo je da

\footnotetext{
${ }^{\text {II } T r o s ̌ k o v i ~ z a ~ p l a c ́ e ~ u ~ H r v a t s k o j ~ u k l j u c ̌ u j u ~ p l a c ́ e ~ i ~ d o p r i n o s e ~ z a ~ s o c i j a l n a ~ o s i g u r a n j a, ~ d o k ~ d r u g i ~ t r o s ̌ k o v i ~ z a ~ z a p o s l e n e ~ n i s u ~}$ uključeni (npr. terenski dodatak i naknada za odvojeni život).
} 
se troškovi za računalne usluge odnose samo na održavanje i podršku postojećih programa, no ne i na nabavku novih programa i/ili hardvera.

\section{TABLICA 4.}

Troškovi za usluge, u mil. kuna, 2004.-I2. *

\begin{tabular}{|c|c|c|c|c|c|c|c|c|c|c|}
\hline Trošak za & 2004. & 2005 & 2006. & 2007. & 2008. & 2009. & 2010. & $20 I I$. & 2012. & $\begin{array}{c}\text { 2012./o4. } \\
\text { (promjena } \\
\text { u \%) }\end{array}$ \\
\hline $\begin{array}{l}\text { usluge telefona, pošte } \\
\text { i prijevoza }\end{array}$ & 48 & IOI & 77 & 85 & 93 & II9 & IOO & 84 & 76 & 57 \\
\hline $\begin{array}{l}\text { usluge tekućeg i } \\
\text { investicijskog održavanja }\end{array}$ & IO & I3 & $2 \mathrm{I}$ & 28 & $3 I$ & $3 I$ & 45 & I3 & 28 & I66 \\
\hline komunalne usluge & I5 & $2 \mathrm{I}$ & $2 \mathrm{I}$ & 23 & 26 & 28 & 28 & 9 & 9 & -44 \\
\hline zakupnine i najamnine & 7 & 9 & $\mathrm{I} 4$ & I8 & I9 & 19 & 24 & 29 & 29 & 323 \\
\hline $\begin{array}{l}\text { intelektualne i osobne } \\
\text { usluge }\end{array}$ & 2 & 3 & 5 & I3 & 26 & 77 & 34 & $\mathrm{I7}$ & $2 \mathrm{I}$ & $84 \mathrm{I}$ \\
\hline računalne usluge (IT) & 3 & 5 & 5 & II6 & 149 & 149 & 156 & 214 & $2 \mathrm{I} 4$ & 7.455 \\
\hline ostale usluge & IO & 13 & 25 & 33 & 26 & 22 & 24 & 43 & 43 & 326 \\
\hline Ukupno & 96 & I65 & 167 & $3 \mathrm{I} 6$ & 369 & 446 & $4 \mathrm{IO}$ & 409 & 420 & - \\
\hline
\end{tabular}

* Podaci se odnose isključivo na troškove financirane iz državnog proračuna. Manji iznosi TPV-a koje su PU, CU i FP financirali vlastitim sredstvima nisu uključeni zbog nedostatka detaljnih podataka.

Izvor: Ministarstvo financija (2000.-I2.).

Iz tablice 4. vidljivo je kako u razdoblju 2004.-I2. u ukupnim troškovima za usluge najviše rastu troškovi računalnih usluga (koji rastu za oko $7.000 \%$, odnosno s oko 3 na gotovo 2 I4 mil. kuna). Znatno su porasli i troškovi za zakupnine i najamnine (za više od 30o\%, odnosno sa 7 na 30 mil. kuna), te troškovi za intelektualne i osobne usluge (za više od 800\%, s 2 na 2I mil. kuna). U apsolutnim iznosima u čitavom razdoblju veliki su i troškovi usluga telefona, pošte i prijevoza (prosječno godišnje iznose oko 9o mil. kuna). Stoga bi PU i CU u budućnosti trebale posebnu pažnju obratiti analizi upravo ovih troškova, te preispitati je li ih moguće i koliko smanjiti.

\section{GRAFIKON 7.}

Kretanje TPV-a i BDP-a u Hrvatskoj, 1997--20I2.

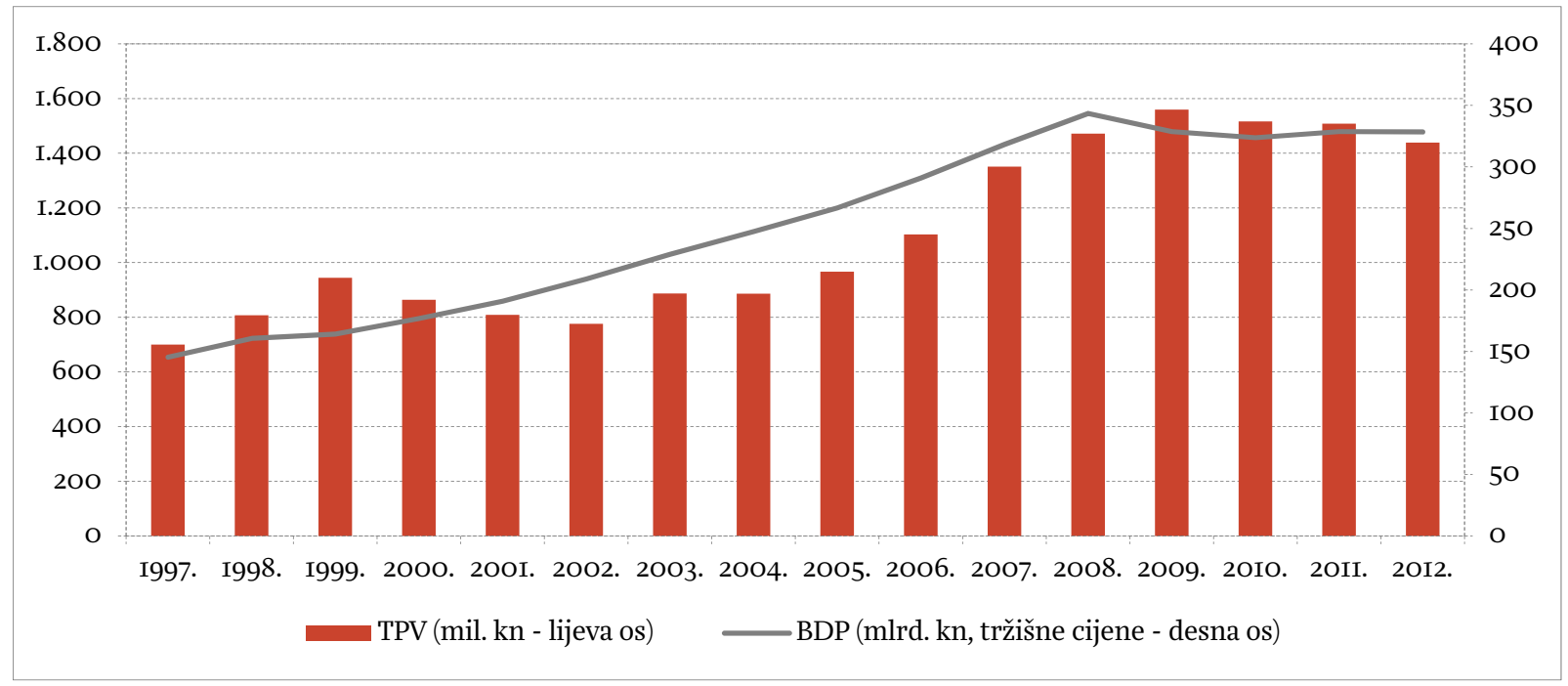

Izvor: Ministarstvo financija (200o.-I2.). 
Konačno, u ovome bi dijelu bilo zanimljivo istražiti postoji li veza između porasta/smanjenja TPV-a i poreznih promjena u Hrvatskoj, odnosno rastu li ukupni TPV-i u godinama u kojima su rađene i najveće porezne promjene $u$ hrvatskom poreznom sustavu. Naime, moguće je pretpostaviti kako svaka promjena poreznih zakona utječe i na povećanje troškova njihova administriranja, te na potrebu povećanja broja zaposlenih uslijed veće složenosti sustava. U dodatku 3. navedene su najznačajnije promjene u Hrvatskoj u razdoblju 1997.-20I2. za najvažnije poreze (porez na dohodak, porez na dobit, PDV i socijalni doprinosi). No, zbog čestih promjena poreznog zakonodavstva (porezne stope i/ili osnovice mijenjaju se gotovo svake godine), gotovo je nemoguće porezne promjene povezati s promjenama ukupnih TPV-a ${ }^{\mathrm{I} 2}$. Zbog toga bi svakako trebalo ukazati na potrebu prikupljanja podataka o troškovima po pojedinim vrstama poreza.

Iz grafikona 7. moglo bi se pretpostaviti kako bi se porast TPV-a u Hrvatskoj u razdoblju 2002.-I2. mogao povezati s rastom gospodarstva (kretanjem BDP-a), odnosno da su PU, CU i FP jednostavno više trošile u razdobljima gospodarskog rasta, a manje kada gospodarstvo pada. No, kako bi se ova veza objasnila potrebne su detaljnije analize, ali iz prethodnih tablica i grafikona vidljivo je kako jedan od razloga može ležati i u činjenici da u razdobljima ekonomskog rasta, izuzev troškova za zaposlene, jako velik porast bilježe i troškovi za računalne usluge (troškovi održavanja i podrške postojećim programima).

\section{ZAKLJUǦGI}

Cilj je ovog rada bio utvrditi je li se u razdoblju 1997--2002. poboljšala učinkovitost poreznih vlasti u Hrvatskoj te identificirati na koje se načine može dodatno povećati. TPV u postotku BDP-a u promatranom razdoblju se smanjio, ali je još uvijek iznad prosjeka zemalja članica EU-a. Zbog toga bi PU i CU trebale intenzivnije pristupiti smanjivanju troškova administriranja. Cilj poreznih vlasti trebao bi biti da uz zadanu poreznu strukturu prikupe maksimalno moguće prihode, ali uz najmanji mogući trošak. Prvi korak koji bi porezne vlasti mogle $u$ tome napraviti je identificirati $i$, ako je moguće, ukinuti problematične poreze koji donose jako malo prihoda, a imaju visoke troškove administriranja. Drugi je provesti iscrpnu analizu TPV-a kako bi se utvrdilo mogu li se smanjiti. Prema provedenoj analizi najveći udio u ukupnim troškovima imaju troškovi za zaposlene, troškovi za računalne usluge te troškovi za usluge telefona, pošte i prijevoza. Posljedično, PU i CU bi posebnu pažnju trebale posvetiti analizi upravo ovih troškova.

Čini se da su TPV u Hrvatskoj u razdoblju 2002.-I2. najvećim dijelom povezani s kretanjem BDP-a, odnosno da PU, CU i FP troše više u razdobljima gospodarskog rasta, a manje kada gospodarstvo pada. Tijekom razdoblja gosodarskog rasta, osim troškova za zaposlene, znatno rastu i troškovi računalnih usluga (troškovi održavanja i podrške postojećih progama).

Kao i u prethodnim analizama (npr. Ott i Bajo, 2000.; Bratić i Pitarević, 2004.; Vitek i Pubal, 2002.), i u ovom su istraživanju prisutni problemi s (ne)dostupnošću i javnosti podataka. Zbog nepostojanja odgovarajućih podataka nije bilo moguće utvrditi TPV po pojedinim vrstama poreza. Ta bi informacija bila korisna kako bi PU i CU uvidjele koji ih porezi najviše administrativno koštaju te kako bi pokušali naći odgovarajuće mjere, ako bude potrebno i/ili moguće, za njihovo smanjenje. Kako bi se uopće dobila bolja slika ukupnih troškova prikupljanja poreza i kako bi ih bilo moguće smanjiti, povrh

\footnotetext{
${ }^{12}$ Osim, možda da su TPV-i dosta porasli i999. budući da se 1998. dogodila vjerojatno najveća porezna promjena (uveden je PDV kao potpuno novi porezni oblik).
} 
istraživanja troškova poreznih vlasti, neophodno je istražiti troškove ispunjavanja porezne obveze svakog pojedinog poreznog oblika jer postoji element prenosivosti između troškova poreznih vlasti i troškova ispunjavanja porezne obveze (izvršna vlast može odgovornost za prikupljanje poreza i njihove troškove dodijeliti samim poreznim obveznicima umjesto poreznoj administraciji). U budućnosti bi svakako trebalo pokušati utvrditi i koliki su troškovi FINA-e (koja za PU i CU neposredno prikuplja poreze i vodi evidenciju), troškovi sudova koji obrađuju pojedinačne porezne i carinske slučajeve, te troškovi Sabora povezani s donošenjem poreznih zakona. 


\section{DODATAK I.}

TPV u pojedinim državama članicama EU-a, u \% BDP-a, 2005.-I2.

\section{TPV/BDP, $\mathbf{u} \%$}

Značajni čimbenici koji utječu na usporedivost udjela među zemljama

2005. 2006. 2007. 2008. 2009. 2010. 2011.

\begin{tabular}{|c|c|c|c|c|c|c|c|c|}
\hline Grčka & n.a. & n.a. & n.a. & n.a. & n.a. & n.a. & n.a. & \\
\hline Hrvatska & 0,36 & 0,38 & 0,43 & 0,43 & 0,48 & 0,47 & 0,45 & PU, CU i FP \\
\hline Mađarska & 0,30 & 0,33 & 0,40 & 0,39 & 0,40 & 0,42 & 0,38 & \\
\hline Malta & n.a. & n.a. & n.a. & n.a. & n.a. & $0,4 \mathrm{I}$ & 0,36 & \\
\hline Belgija & 0,38 & 0,36 & 0,34 & 0,34 & 0,35 & 0,33 & 0,35 & \\
\hline Nizozemska & 0,42 & $0,4 \mathrm{I}$ & 0,39 & 0,35 & 0,37 & 0,35 & 0,33 & \\
\hline Slovenija & n.a. & n.a. & 0,26 & 0,27 & 0,28 & 0,29 & 0,29 & \\
\hline Njemačka & 0,30 & 0,29 & 0,28 & 0,28 & 0,29 & 0,29 & 0,28 & \\
\hline Portugal & 0,26 & 0,25 & 0,25 & 0,25 & 0,27 & 0,27 & 0,26 & \\
\hline Poljska & $\mathrm{O}, 3 \mathrm{I}$ & 0,29 & 0,28 & 0,24 & 0,23 & 0,27 & 0,25 & \\
\hline Cipar "* & n.a. & n.a. & n.a & O,I8 & O,I9 & 0,25 & 0,25 & \\
\hline Irska & 0,24 & 0,24 & 0,24 & 0,27 & 0,29 & 0,26 & 0,25 & Troškovi uključuju carine \\
\hline Velika Britanija & n.a. & n.a. & 0,34 & 0,28 & 0,29 & 0,27 & 0,24 & \\
\hline Prosjek EU-a & 0,28 & 0,27 & 0,40 & 0,32 & 0,32 & $\mathbf{0 , 3 I}$ & 0,23 & \\
\hline Rumunjska & n.a. & n.a. & 0,25 & 0,23 & 0,20 & 0,13 & 0,23 & \\
\hline Francuska & 0,26 & 0,25 & 0,24 & 0,23 & 0,24 & 0,23 & 0,23 & \\
\hline Bugarska & 0,33 & 0,25 & $0,2 \mathrm{I}$ & 0,22 & 0,24 & 0,24 & 0,23 & \\
\hline Latvija & n.a. & n.a. & 0,35 & 0,36 & 0,34 & 0,29 & 0,23 & \\
\hline Luksemburg & 0,25 & 0,22 & 0,22 & 0,23 & 0,25 & 0,23 & 0,22 & \\
\hline Finska & $0,2 \mathrm{I}$ & $0,2 \mathrm{I}$ & 0,20 & $0,2 \mathrm{I}$ & 0,23 & $0,2 \mathrm{I}$ & $0,2 \mathrm{I}$ & \\
\hline Danska & 0,37 & 0,30 & 0,29 & 0,30 & $0,3 \mathrm{I}$ & $0,2 \mathrm{I}$ & 0,20 & \\
\hline Češka & 0,22 & 0,22 & 0,20 & 0,19 & 0,20 & O,I9 & 0,20 & \\
\hline Slovačka & 0,22 & 0,20 & $\mathrm{O}, \mathrm{I} 7$ & n.a. & n.a. & O,I8 & 0,18 & \\
\hline Italija $^{* *}$ & 0,27 & 0,26 & 0,29 & O,I9 & $\mathrm{O}, 2 \mathrm{I}$ & O,I9 & 0,17 & Neki ključni troškovi nisu uključeni \\
\hline Švedska & O,I9 & O,I9 & O,I9 & $\mathrm{O}, \mathrm{I} 8$ & O,I8 & $\mathrm{O}, \mathrm{I} 8$ & $\mathrm{O}, \mathrm{I7}$ & $\begin{array}{l}\text { Troškovi ne uključuju sakupljanje } \\
\text { dugova }\end{array}$ \\
\hline Litva & n.a. & n.a. & 0,23 & 0,22 & $\mathrm{O}, 2 \mathrm{I}$ & 0,17 & O,I6 & \\
\hline Austrija & n.a. & n.a. & 0,15 & O,I9 & 0,20 & O,I6 & 0,15 & \\
\hline Španjolska & n.a. & n.a. & O,I3 & O,I3 & O,I3 & O,I3 & 0,13 & Troškovi uključuju carine \\
\hline Estonija & n.a. & n.a. & 3,69 & I,9I & $\mathrm{I}, 86$ & $\mathrm{I}, 82$ & O,II & \\
\hline
\end{tabular}

* BDP tržišne cijene, u milijunima, nacionalne valute.

** Cipar: Revidirani podaci kako bi se otkrile greške u izvorno korištenim podacima. Uplate drugih tijela vlasti izvršene u ime Uprave za prihode (eng. IRD, Inland Revenue Department) i za PDV ne vide se u ovim specifičnim godinama.

Italija: Izračun do 2009. temelji se na podacima o troškovima za obavljanje poreznih funkcija tijela zaduženog za prihode (Agenzia Entrate), za porezne poslove posebno ustrojenog policijskog tijela koji se bavi porezima (Guardia di Financia) te za posebno ustrojeno tijelo za prikupljanje poreznog duga (Equitalia); nisu prikazani podaci za naredne godine.

Izvor: OECD, 2OI3. 
DODATAK 2.

Ukupni porezni prihodi konsolidarane opće države, u \%, Hrvatska, 200o.-I2.

\begin{tabular}{|c|c|c|c|c|c|c|c|c|c|c|c|c|c|c|}
\hline & 2000. & 2001. & 2002. & 2003. & 2004. & 2005. & 2006. & 2007. & 2008. & 2009. & 2010. & 2011. & 2012. & $\begin{array}{r}\text { Prosjek } \\
2000 .-12 .\end{array}$ \\
\hline Porez na dohodak & II,5 & 9,6 & 9,5 & 8,9 & 9,0 & 8,5 & 8,8 & 9,0 & 8,9 & $9, \mathrm{I}$ & 8,4 & 8,5 & 8,8 & 9,I \\
\hline Porez na dobit & 3,7 & 4,2 & 4,9 & 5,3 & $5, \mathrm{I}$ & 6,I & $7, \mathrm{I}$ & 8,0 & 8,8 & 8,3 & 5,8 & 6,7 & 6,9 & 6,2 \\
\hline Socijalni doprinosi & $3 \mathrm{I}, 2$ & $32, \mathrm{I}$ & 33,2 & 33,7 & 34,3 & $34, \mathrm{I}$ & 33,7 & 33,6 & 33,8 & 35,2 & $35, \mathrm{I}$ & 35,5 & 33,8 & 33,8 \\
\hline Porez na platnu listu & 0,0 & 0,0 & 0,0 & 0,0 & 0,0 & 0,0 & 0,0 & 0,0 & 0,0 & 0,0 & $\mathrm{O}, \mathrm{O}$ & 0,0 & 0,0 & 0,0 \\
\hline Porezi na imovinu* & $\mathrm{I}, 2$ & $\mathrm{I}, \mathrm{O}$ & 0,8 & 0,7 & 0,9 & $\mathrm{o}, 8$ & $\mathrm{I}, \mathrm{O}$ & $\mathrm{I}, \mathrm{O}$ & $\mathrm{I}, \mathrm{O}$ & 0,9 & 0,8 & 0,8 & 0,7 & 0,9 \\
\hline PDV & 33,6 & 34,7 & 34,2 & 34,8 & 35,0 & 35,3 & 34,7 & $34, \mathrm{I}$ & 34,5 & 32,8 & 34,3 & 34,7 & 36,3 & 34,5 \\
\hline Ostali porezi na potrošnju ${ }^{* *}$ & 0,5 & 0,4 & $\mathrm{I}, \mathrm{O}$ & 0,9 & $\mathrm{I}, \mathrm{I}$ & $\mathrm{I}, \mathrm{I}$ & $\mathrm{I}, 4$ & $\mathrm{I}, 4$ & $\mathrm{I}, 2$ & $\mathrm{I}, 2$ & $\mathrm{I}, 4$ & $\mathrm{I}, 6$ & $\mathrm{I}, 6$ & $\mathrm{I}, \mathrm{I}$ \\
\hline $\begin{array}{l}\text { Porezi na međunarodnu } \\
\text { trgovinu i transakcije }\end{array}$ & 5,8 & 4,8 & 2,7 & 2,2 & I,9 & $\mathrm{I}, 7$ & $\mathrm{I}, 6$ & $\mathrm{I}, 5$ & $\mathrm{I}, 6$ & $\mathrm{I}, 5$ & $\mathrm{I}, 5$ & $\mathrm{I}, 6$ & I,6 & 2,3 \\
\hline Drugi porezi & 0,7 & 0,7 & 0,6 & 0,4 & 0,4 & 0,4 & 0,3 & 0,3 & 0,3 & $\mathrm{I}, 2$ & 2,0 & 0,3 & 0,3 & 0,6 \\
\hline Ukupno & IOO,O & IOO,O & IOO,O & IOO,O & IOO,O & IOO,O & IOO,O & IOO,O & IOO,O & IOO,O & IOO,O & IOO,O & IOO,O & \\
\hline
\end{tabular}

* Porezi na imovinu su: porez na promet; porez na nasljedstva i darove, porez na korištenje javnih površina i porez na kuće za odmor.

** Ostali porezi na potrošnju, izuzev PDV-a i trošarina su: porez na cestovna motorna vozila, porez na plovila, porez na automate za zabavne igre, porez na tvrtku ili naziv, porez na dobitke od igara na sreću. Izvor: Ministarstvo financija (2012.), IMF (2014.) 


\section{DODATAK 3.}

Osnovne promjene poreza na dohodak, poreza na dobit, PDV-a i socijalnih doprinosa, 1997.-2OI2.

\section{Promjena}

\section{Porezne osnovice}

1997.

PDOH - povećava se OO sa 700 na 800 kuna;

- uvode se olakšice za HRVI

1998. PDV - uvodi se PDV (opća stopa 22\%)

\section{Porezne stope}

PDOH - umjesto stopa s 25\% i 35\% uvedene stope 20\% i 35\%

PDOB - povećanje opće stope s $25 \%$ na $35 \%$

DOPRI - smanjuje se ukupna stopa doprinosa na mirovinsko osiguranje s 25,5\% na 21,5\%;

- povećava se ukupna stopa doprinosa na zdravstveno osiguranje s $14 \%$ na $18 \%$;

- ukida se doprinos za dječji doplatak i vodni doprinos

1999. PDOH - OO se povećava na I.ooo kuna $\quad$ PDV - uvodi se o\% na određene proizvode

PDV - proširuje se lista proizvoda koji se oporezuju s o\%

200o. $\mathrm{PDOH}-\mathrm{OO}$ se povećava na I.250 kuna

PDOB - uvode se poticaji ulaganja

PDV - proširuje se lista proizvoda koji se oporezuju s o\%

OH - umjesto stopa 20\% i 35\% uvedene stope $15 \%, 25 \%$ $35 \%$

PDOH - uvode se četiri nove olakšice (poticaji

zapošljavanja; poticaji obrazovanja i izobrazbe; olakšica za

premije osiguranja koje uplaćuju porezni obveznici

tuzemnim osiguravateljima; olakšica za samostalne

djelatnosti na PPDS i u Gradu Vukovaru koje dohodak

utvrđuju kao razliku između primitaka i izdataka na

temelju poslovnih knjiga)

PDOB - opća stopa snižena na 20\% mirovinsko osiguranje s 2I, $5 \%$ na $19,5 \%$;

- smanjuje se ukupna stopa doprinosa na zdravstveno osiguranje s I8 na I6\% \%

PDOB - uvodi se oporezivanje dividendi za inozemne pravne osobe;

- mijenjaju se olakšice za PPDS i poticaji ulaganja;

- uvode se olakšice za Grad Vukovar, poticaji zapošljavanja i poticaji za osobe s invaliditetom

PDOH - uvodi se olakšica za BPP

2002. $\quad$ PDOB - uvode se olakšice za BPP

DOPRI - uvodi se posebni doprinos za osiguranje od posljedica ozljede na radu i profesionalne bolesti $(0,47 \%)$

PDOH - mijenjaju se rasponi na koje se primjenjuju porezne stope;

- OO se povećava na I.5Oo kuna;

- uvode se dvije nove olakšice (poticanje istraživanja i razvoja te izdaci za zdravstvenu zaštitu i stambene potrebe)

2003.

PDOB - uvode se poticaji za istraživanje i razvoj te za školovanje i usavršavanje

DOPRI - ukida se doprinos za mirovinsko osiguranje na plaću i doprinos za zdravstveno osiguranje iz plaće

PDOH - umjesto stopa s I5\%, 25\% i 35\% uvedene stope $15 \%$, $25 \%, 35 \%$ i $45 \%$

DOPRI - povećava se ukupna stopa doprinosa za mirovinsko osiguranje s $19,5 \%$ na $20 \%$,

- smanjuje se ukupna stopa doprinosa za zdravstveno osiguranje sa $16,47 \%$ na $15,5 \%$

PDOH - mijenjaju se rasponi na koje se primjenjuju porezne stope;

- OO se povećava na I.6oo kuna

PDOB - ukida se oporezivanje dividendi za ino. pravne

osobe;

- uvode se olakšice za trgovačka društva koja obavljaju brodarsku djelatnost

DOPRI - uvodi se posebni doprinos za poticanje zapošljavanja osoba s invaliditetom 


\section{Promjena}

Porezne osnovice

Porezne stope

PDV - proširuje se lista proizvoda koja se oporezuju s IO\%

PDOH - uvodi se nova olakšica (umanjenje paušalnog

plaćanja poreza na dohodak od obrta, osim ugostiteljstva i

trgovine, i poljoprivrede na PPDS, BPP, Gradu Vukovaru i

2007. otocima prve skupine)

PDOB - ukidaju se poticaji za osobe s invaliditetom i poticaji zapošljavanja

- mijenjaju se tri olakšice (poticaji za ulaganja, poticaji

za istraživanje i razvoj te poticaji za školovanje i

usavršavanje)

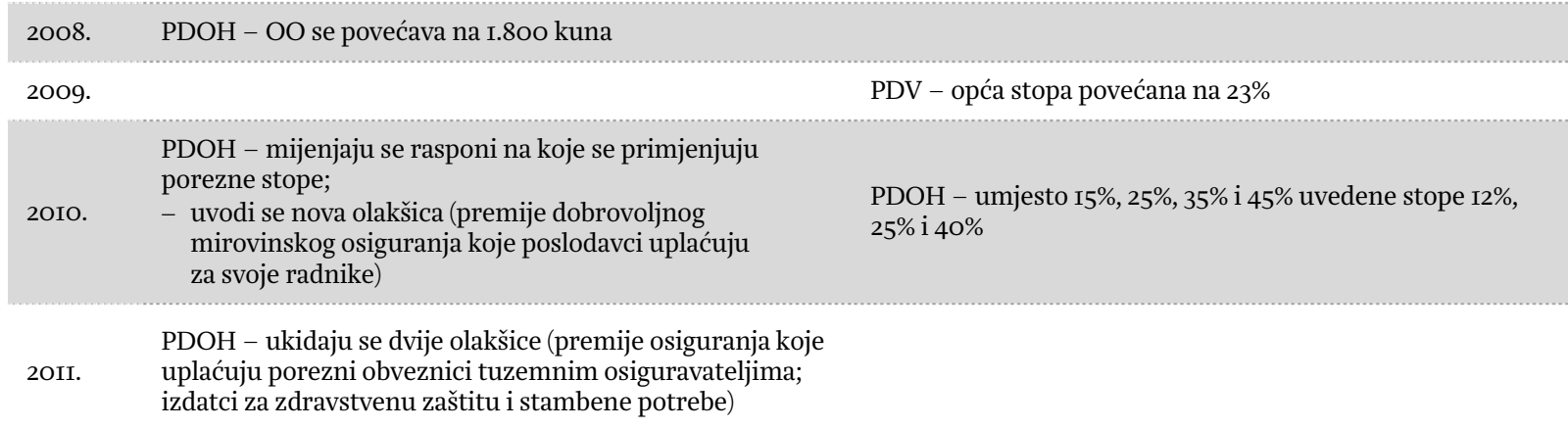

PDV - proširuje se lista proizvoda koja se oporezuju s IO\%

PDOH - OO se povećava na 2.200 kuna;

- mijenjaju se rasponi na koje se primjenjuju porezne stope

2012.

PDOB - uvodi se oporezivanje dividendi i udjela u dobiti

PDV - opća stopa povećana na $25 \%$

za ino. pravne osobe

- poticaji ulaganja zamjenjuju se sličnom olakšicom poticajima za investicije i unapređenje investicijskog okruženja

DOPRI - stopa doprinosa za zdravstveno osiguranje smanjuje se s $15 \%$ na $13 \%$

Kratice: BPP - brdsko planinska područja; DOP - doprinosi za obvezna osiguranja; HRVI- hrvatski ratni vojni invalidi; OO - osnovni osobni odbitak (nije uključen osobni odbitak umirovljenika); PDOB - porez na dobit; PDOH - porez na dohodak; PPDS - područja od posebne državne skrbi; PDV - porez na dodanu vrijednost.

Izvor: Zakon o porezu na dodanu vrijednost, Zakon o porezu na dobit, Zakon o porezu na dohodak, Zakon o doprinosima. 


\section{REFERENGE}

I. Allers, M., 1994. Administrative and Compliance Costs of Taxation and Public Transfers in the Netherlands. Groningen: Woltersgroep.

2. Blažić, H., 2004. Troškovi oporezivanja u Hrvatskoj: troškovi poreznih obveznika i troškovi poreznih vlasti. Financijska teorija $i$ praksa, 28(3), str. 27I-29I. Dostupno na: 〈http://www.ijf.hr/FTP-/2004/3/blazicr.pdf〉.

3. Bratić, V. i Pitarević, M., 2004. Troškovi poreznih vlasti u Hrvatskoj. Financijska teorija i praksa, 28(3), str. 377-399. Dostupno na: 〈http://www.ijf.hr/FTP/2004/3/bratic-pitarevic.pdf〉.

4. Bratić, V. i Šimović, H., 20Io. Usporedba troškovne učinkovitosti porezne administracije u Hrvatskoj sa zemljama OECD-a. Hrvatska javna uprava : časopis za teoriju i praksu javne uprave, Io (I), str. I63-I80. Dostupno na: <https://bib.irb.hr/datoteka/469IO5.2OIOI_O7_Bratic_Simovic.pdf $>$.

5. Carinska uprava, I997.-20I2. Izvješća o broju zaposlenih, ukupnim godišnjim vlastitim prihodima CU te ukupnim godišnjim troškovima CU financiranim iz vlastitih sredstava CU za razdoblje 1997.-2OI2. Zagreb: Ministarstvo financija, Carinska uprava.

6. Carinska uprava, 2005.-I2. Izvještaj o prihodima i rashodima, primicima i izdacima za razdoblje 2005.I2. Zagreb: Ministarstvo financija, Carinska uprava.

7. Chittenden, F., Foster, H. i Sloan B., 20Io. Taxation and Red Tape: The Cost to British Business of Complying with the UK Tax System. London: The Institute of Economic Affairs.

8. Evans, C., Pope J. i J. Hasseldine (eds.), 200I. Tax Compliance Costs: A Festschrift for Cedric Sanford. St Leonards: Prospect Media Pty Ltd.

9. Evans, C., 2003. Studying the Studies: An Overview of Recent Research into Taxation Operating Costs. Journal of Tax Research, I(I), str. 64-92.

IO. Evans, C, 2006. Counting the costs of taxation: an exploration of recent developments in London School of Economics Capital Markets seminar series, presented at London School of Economics Capital Markets seminar series, London, England, I6 October 2006.

II. FINA, 20I2. Godišnji izvještaj o poslovanju financijske agencije za 20II. godinu. Dostupno na: 〈www.fina.hr/lgs.axd?t=I6\&id=I3673〉.

I2. IMF, 20I4. GFS March 20I4. Washington: International Monetary Fund. Dostupno na: $<$ http://elibrary-data.imf.org/>.

13. Lignier, P. i Evans, C., 2012. The Rise and Rise of Tax Compliance Costs for the Small Business Sector in Australia, Australian Tax Forum, 27 (3), str. 615-672.

I4. Ministarstvo financija, 2000.-I2. Godišnji izvještaj o izvršenju državnog proračuna Republike Hrvatske u razdoblju 200o.-I2. Zagreb: Ministarstvo financija.

15. Ministarstvo financija, 20I2. Statistički prikaz, No. 217. Dostupno na: 〈http://www.mfin.hr/adminmax/docs/2I7\%2OLISTOPAD\%2O2OI3.pdf>.

I6. Naredba o načinu uplaćivanja prihoda proračuna, obveznih doprinosa te prihoda za financiranje drugih javnih potreba u 2OI4. godini, NN I7/I4. Zagreb: Narodne novine.

17. OECD, 2004. Tax Administration in OECD and Selected Non-OECD Countries: Comparative Information Series 2004. Dostupno na: 〈http://www.oecd.org/ctp/administration/CIS-2004.pdf 〉.

18. OECD, 2006. Tax Administration in OECD and Selected Non-OECD Countries: Comparative Information Series 2006. Dostupno na: 〈http://www.oecd.org/ctp/consumption/CIS-20o6.pdf.

19. OECD, 2009. Tax Administration in OECD and Selected Non-OECD Countries: Comparative Information Series 2008. Dostupno na: 〈http://www.oecd.org/ctp/administration/CIS-2008.pdf .

20. OECD, 20II. Tax Administration in OECD and Selected Non-OECD Countries: Comparative Information Series 20Io. Dostupno na: 〈http://www.oecd.org/ctp/administration/CIS-2OIO.pdf〉.

21. OECD, 2013. Tax Administration 2013: Comparative Information on OECD and Other Advanced and Emerging Economies. Dostupno na: <http://www.oecd.org/ctp/administration/taxadministration-series.htm>.

22. Opći porezni zakon, NN I47/O8, I8/II, 78/I2, I36/I2, 73/I3. Zagreb: Narodne novine.

23. Ott, K. i Bajo, A., 200o. Troškovi oporezivanja u tranzicijskim zemljama: iskustvo Hrvatske. Financijska teorija i praksa, 24(2), str. 169-188.

24. Porezna uprava, 1995.-2006. Izdaci Porezne uprave u odnosu na financijski plan proračuna u razdoblju 1995.-2006. Zagreb: Ministarstvo financija, Porezna uprava.

25. Porezna uprava, 2002.-I2. Izvještaj o prihodima i rashodima, primicima i izdacima u razdoblju 2002-I2. Zagreb: Ministarstvo financija, Porezna uprava.

26. Sandford, C. (ed.), 1995. Tax Compliance Costs Measurement and Policy. Bath: Fiscal Publications. 
27. Sandford, C., I994. International Comparisons of Administrative and Compliance Costs of Taxation. Australian Tax Forum, II(3), str. 29I-309.

28. Sandford, C., 1995. Minimising Administrative and Compliance Cost. In: C. Sandford, ed. More Key Issues in Tax Reform. Bath: Fiscal Publications.

29. Sandford, C., 2000. Why Tax Systems Differ: A Comparative Study of the Political Economy of Taxation. Bath: Fiscal Publications.

30. Sandford, C., Godwin, M. and Hardwick, P., 1989. Administrative and Compliance Costs of Taxation. Bath: Fiscal Publications.

3I. Vitek, L. i Pubal, K., 2002. Evaluation of the Effectiveness of the Tax Collection - the Case of the Czech Central and Local Governments in the Czech Republic in: Delivering Public Services in CEE Countries: Trends and Developments, ed.: Jan Finlay and Marek Debicky. Bratislava: NISPAcee. str. 485. Dostupno na: <http://unpani.un.org/intradoc/groups/public/documents/NISPAcee/UNPANo04338.pdf $>$.

32. Zakon o carinskoj službi, NN 53/9I, IO6/93, 67/oI, 83/o9, 49/II, 34/I2, 68/I3 and 30/I4. Zagreb: Narodne novine.

33. Zakon o doprinosima, NN I47/O2, I75/O3, I77/O4, 84/O8, I52/O8, 94/O9, I8/II, 22/I2, I44/I2, I48/13, 4I/I4. Zagreb: Narodne novine.

34. Zakon o financijskoj policiji, NN 89/92, I6/93, 94/93, 28/94, I77/O4, 55/II, 25/I2,. Zagreb: Narodne novine.

35. Zakon o Poreznoj upravi, NN 7I/99, NN 67/OI, NN 94/or. Zagreb: Narodne novine.

36. Zakon o porezu na dobit, NN I09/93, I06/96, I27/OO, I63/O3, I77/O4, I8I/O4, 90/O5, 57/o6, I46/O8, 80/IO, 22/I2, I48/I3. Zagreb: Narodne novine.

37. Zakon o porezu na dodanu vrijednost, NN 47/95, I06/96, I64/98, I05/99, 54/oo, 73/oo, 90/o5, 76/o7, 94/o9, 87/o9, 22/I2, 136/I2, 73/13, I48/13. Zagreb: Narodne novine.

38. Zakon o porezu na dohodak, NN I06/96, I64/98, 33/o0, I27/oO, I5O/O2, I63/O3, 30/O4, I77/O4, 73/o8, 8O/IO, II4/II, 22/I2, I44/I2, I25/I3, I48/I3. Zagreb: Narodne novine. 